\title{
PHOTOGRAMMETRY-BASED SPATIAL ANALYSES OF SETTLEMENTS IN SEVERYNIVKA AND NEMYRIV
}

\begin{abstract}
During the Polish-Ukrainian archaeological project "Fortresses of Ukraine" it was proposed to study two of the most significant sites with the newest possible technology. The final decision was made to apply the digital photogrammetry that was acquired with the use of drones.
\end{abstract}

ABSTRACT

Key words: photogrammetry, Scythian time, hillfort, fortification, defensive structures, Early Iron Age

A significant obstacle towards the study of the settlements of the forest-steppe zone in the Pontic area was their size and the construction of the fortifications. In Nemyriv the size of the settlement ranged from 100 ha [Smirnova 1996: 67] to 250 ha, with the final version being 145 ha [Daragan 2010: 38-41]. Similar inaccuracies were recorded for other sites. Due to the constant erosion of the escarpment, caused by the construction of a railway track in the $19^{\text {th }}$ century, the area of sites is constantly decreasing. As a result, the descriptions presented by G.I. Smirnova [Smirnova 1961: 89-92] and B.M. Lobay [Lobay 1986] are no longer valid.

During the Polish-Ukrainian archaeological project "Fortresses of Ukraine", it was proposed to study two of the most significant sites with the newest possible technology. Due to the size of the settlements in Nemyriv and Severynivka, the possibility of measuring the sites using ground methods was rejected. However, the application of LIDAR, which requires renting an airplane and employing a company with the necessary equipment, would generate costs, exceeding the financial

\footnotetext{
* Institute of Archaeology, Adam Mickiewicz University, Umultowska 89D, 61-614 Poznań, Poland, e-mail: m.lawniczak88@gmail.com
} 
possibilities of the project. The final decision was made to apply the digital photogrammetry that was acquired with the use of drones.

Similar to LIDAR, this method allows for the creation of a point cloud, which is a model of a particular object. The difference is that while LIDAR requires laser scanning, photogrammetry requires the processing of multiple photographs in a specifically designed software, which allows for the identification of shapes and the generation of a high-resolution point cloud. As a result, photogrammetry allows for an effect similar to LIDAR. Using Total Station/GPS receivers and RTK GPS it is possible to acquire precise measurements which after implementation of the software, makes a cloud point metric and allows dimensioning. The drawback of photogrammetry, especially compared to LIDAR, is that it does not allow or the elimination of vegetation, which makes it inapplicable for archaeological sites located in forested areas or covered with dense flora. As a result, the model exported to GIS software is not, as in the case of LIDAR, a Digital Elevation Model (DEM) but a Digital Surface Model (DSM) [Bernasik 2008: 74], which comprises of all objects covering the ground, including trees, bushes, grass and buildings, etc. [Wężyk 2015: 62].

In the case of the two selected sites, vegetation was not a significant obstacle. In Nemyriv it was only identified in the ravines located in the centre of the site, while in Severynivka the whole area was covered with single trees and bushes. The most significant areas, i.e. the remains of the fortifications were devoid of any concentrations of tress or bushes, which would require a different approach. The uniform height of the grass did not present an obstacle for conducting the measurements.

Photographs were taken in July 2015, during two days of constant air survey conducted with a Leica Aibot X6 drone. The point cloud was generated by Geocartis Ltd. They both provided the basis for generating the representation of the rampart's cross-section, as well as the escarpment in Severynivka, in FugroViewer software. The images of the site and their measurements were prepared in $\mathrm{Fu}$ groViewer and ArcScene.

\section{SEVERYNIVKA}

The present-day area of the site is ca. 5.5 ha. The southern rampart is $219 \mathrm{~m}$ long (Fig. 1, 2, 3, 4). The width of the ditch measures $14 \mathrm{~m}$, while the average depth of the ditch is $3.12 \mathrm{~m}$ (Fig. 5). The rampart is ca. $5.70 \mathrm{~m}$ high on both sides, while its width is $18 \mathrm{~m}$ (Fig. 6).

The south-eastern fortifications are $278 \mathrm{~m}$ long and are divided into two segments: the first - main one - marked from the south-eastern rampart (Fig. 7) and 


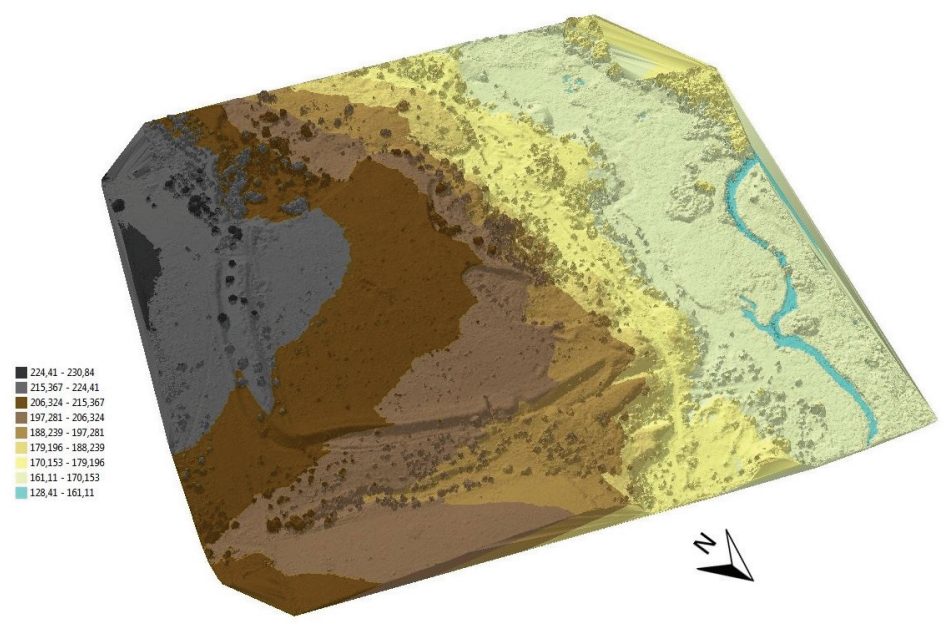

Fig. 1. Severynivka, Vinnytsia Oblast. North-east view of the site - hypsometry

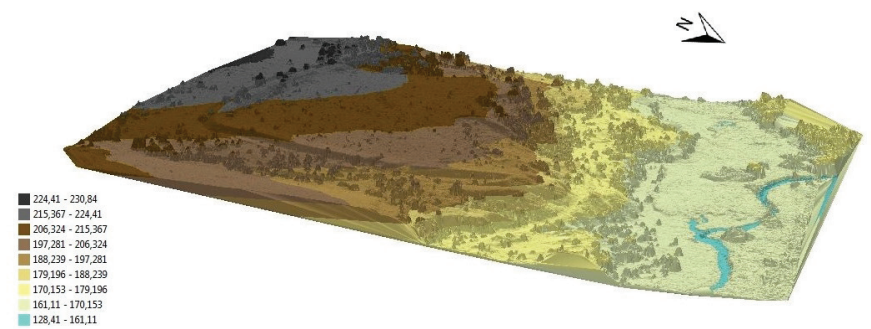

Fig. 2. Severynivka, Vinnytsia Oblast. North-west view of the site - hypsometry

the second located west of it (Fig. 9). The first is slightly elevated in relation to the interior of the settlement and more elevated on the exterior, where it measures approx. $4.6 \mathrm{~m}$ (Fig. 8). A natural ravine was most likely used as a ditch, and it was located $60 \mathrm{~m}$ westwards of the rampart (Fig. 8). The second section of the fortification is located northwards and is characterised by a lack of a rampart and a ditch, being only an undercut escarpment with an average height of $5.55 \mathrm{~m}$ (Fig. 10).

The western escarpment is strongly deformed as a result of soil extraction during the construction of the adjacent railway. Now it is difficult to estimate its original shape and slope. The present profile from the north-western side (Fig. 11) indi- 


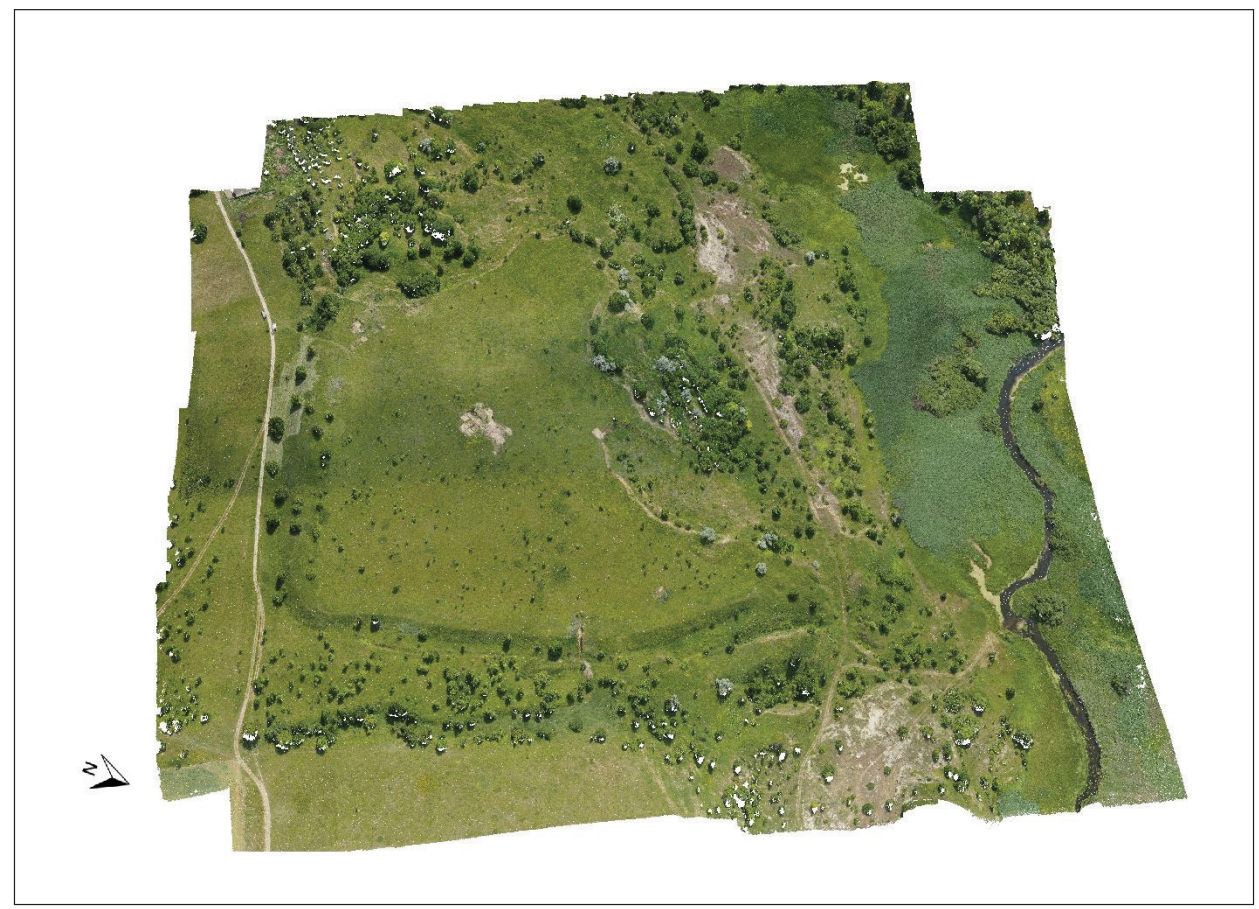

Fig. 3. Severynivka, Vinnytsia Oblast. North-east view of the site - a point cloud.

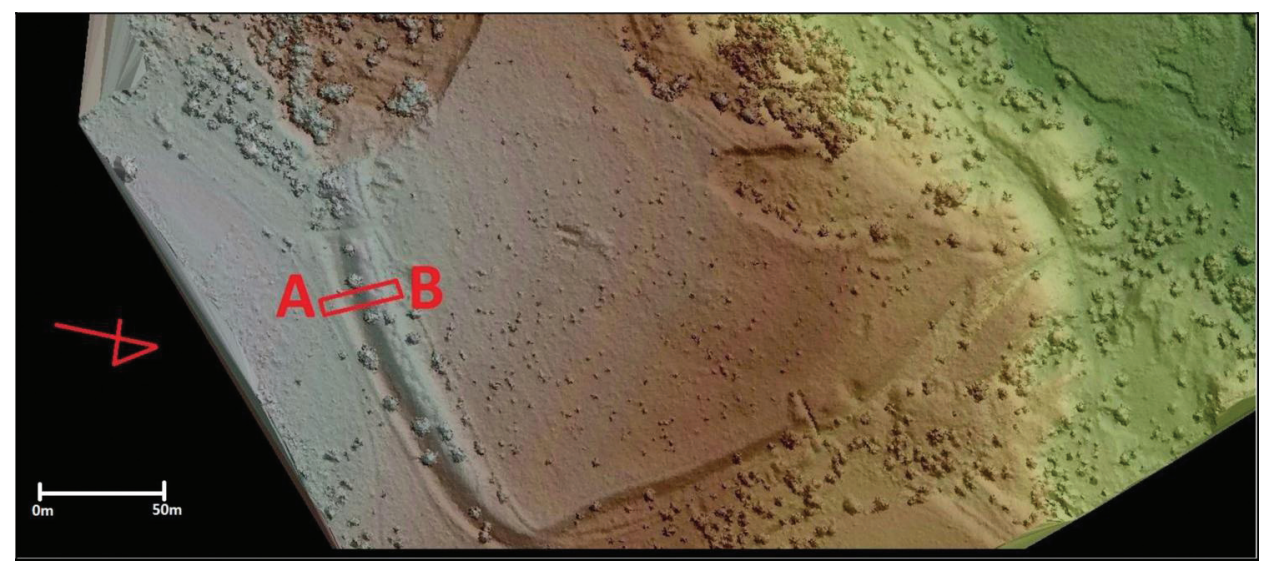

Fig. 4. Severynivka, Vinnytsia Oblast. Location of a cross-section in the south-eastern line of fortifications 


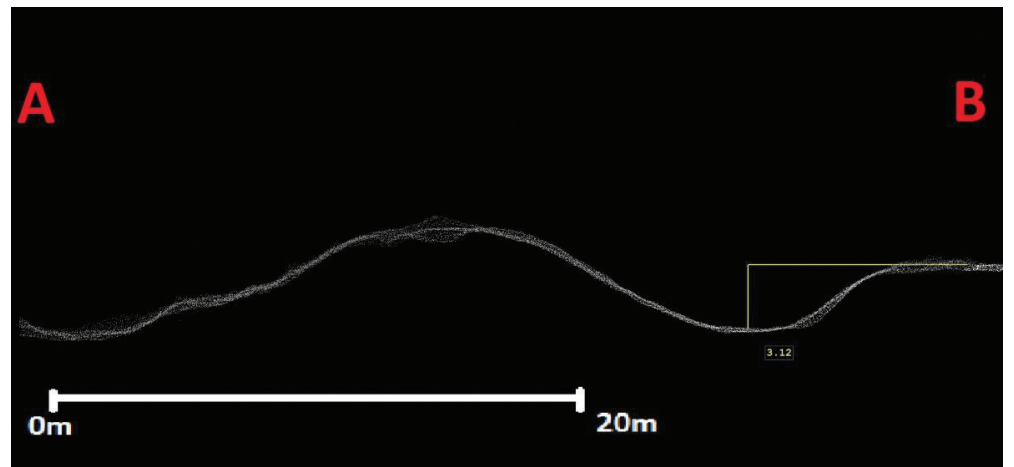

Fig. 5. Severynivka, Vinnytsia Oblast. Cross-section of the moat in the south-eastern part of the hillfort. Dimensions given in metres

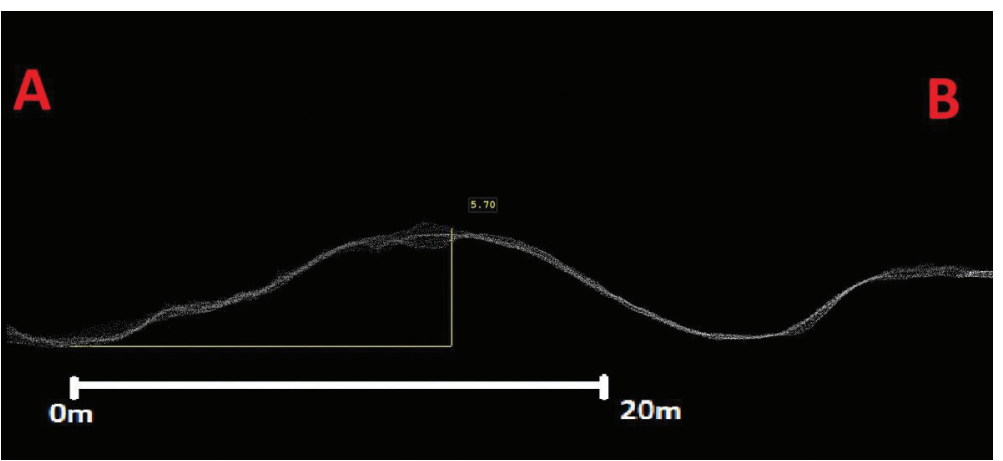

Fig. 6. Severynivka, Vinnytsia Oblast. Cross-section of south-eastern rampart. Dimensions given in metres

cates that its drop measures $30.4 \mathrm{~m}$ at a length of $80 \mathrm{~m}$, which indicates a $35.5 \%$ slope (Fig. 12). The profile of the escarpment from the western side (Fig. 13) measures $31 \mathrm{~m}$ on the length of $133 \mathrm{~m}$ with a slope of $22.7 \%$ (Fig. 14). 


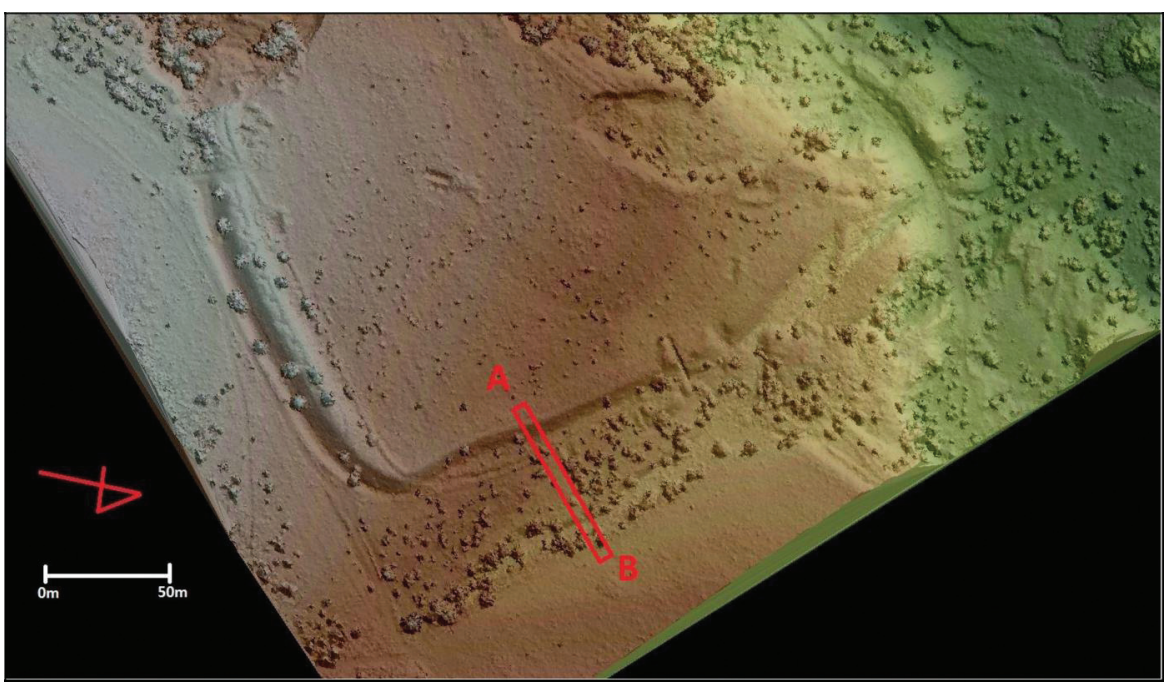

Fig. 7. Severynivka, Vinnytsia Oblast. Location of cross-section in the north-eastern line of fortifications. Main segment

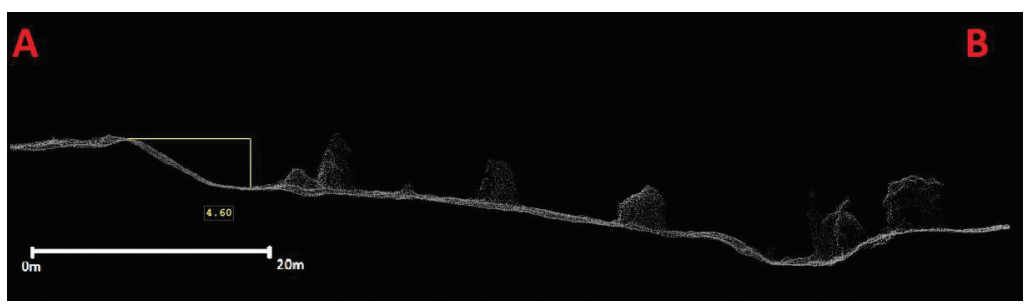

Fig. 8. Severynivka, Vinnytsia Oblast. Cross-section of the rampart in the north-eastern part of fortifications. Main segment. To the right, a natural ravine, perhaps used as a moat. Dimensions given in metres

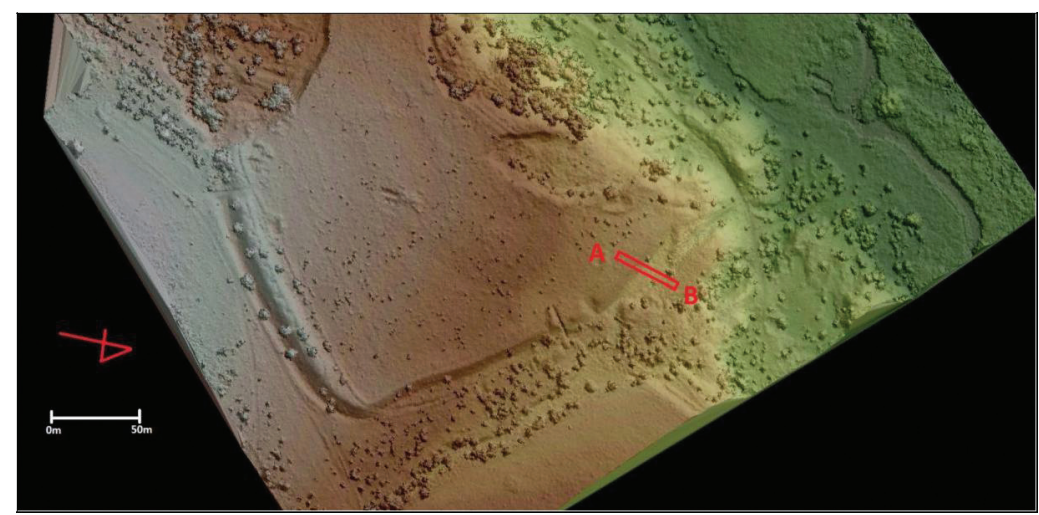

Fig. 9. Severynivka, Vinnytsia Oblast. Location of cross-section in the north-eastern line of fortifications. Side segment 


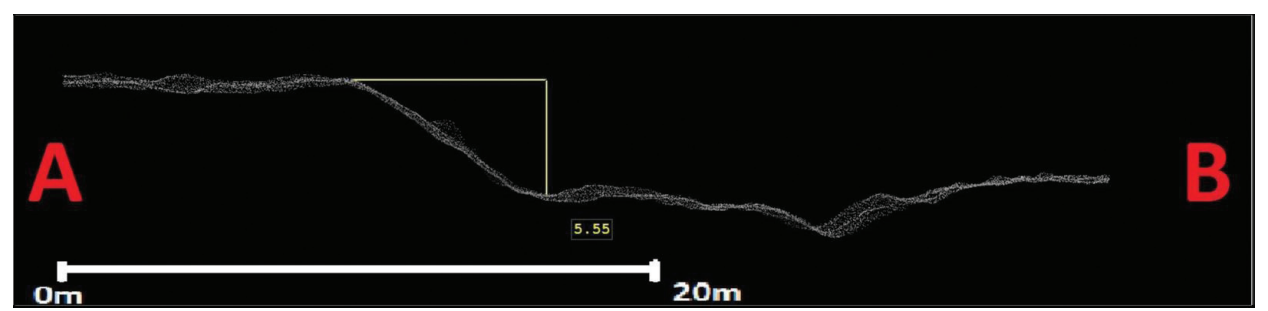

Fig. 10. Severynivka, Vinnytsia Oblast. Cross-section of fortifications in the north-eastern part of the hillfort. North segment. Dimensions given in metres

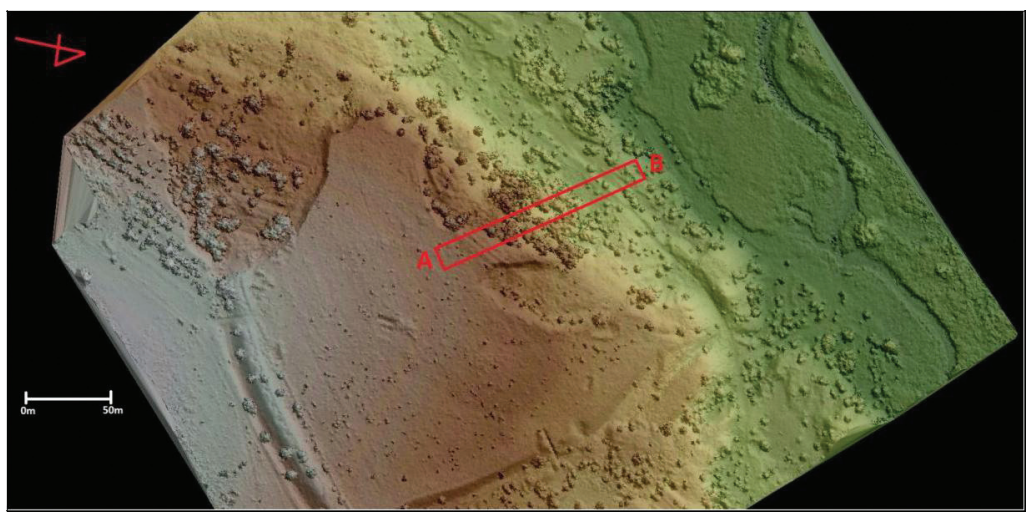

Fig. 11. Severynivka, Vinnytsia Oblast. Location of cross-section in the north-western escarp

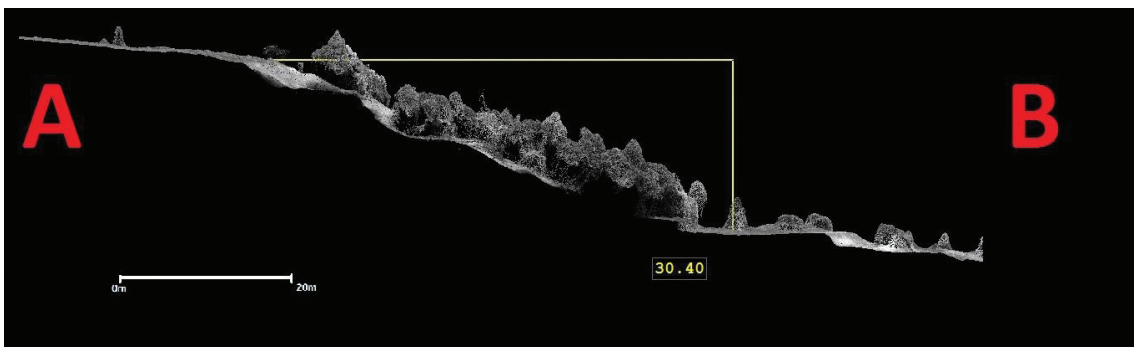

Fig. 12. Severynivka, Vinnytsia Oblast. Cross-section of the north-western escarp. Dimensions given in metres 


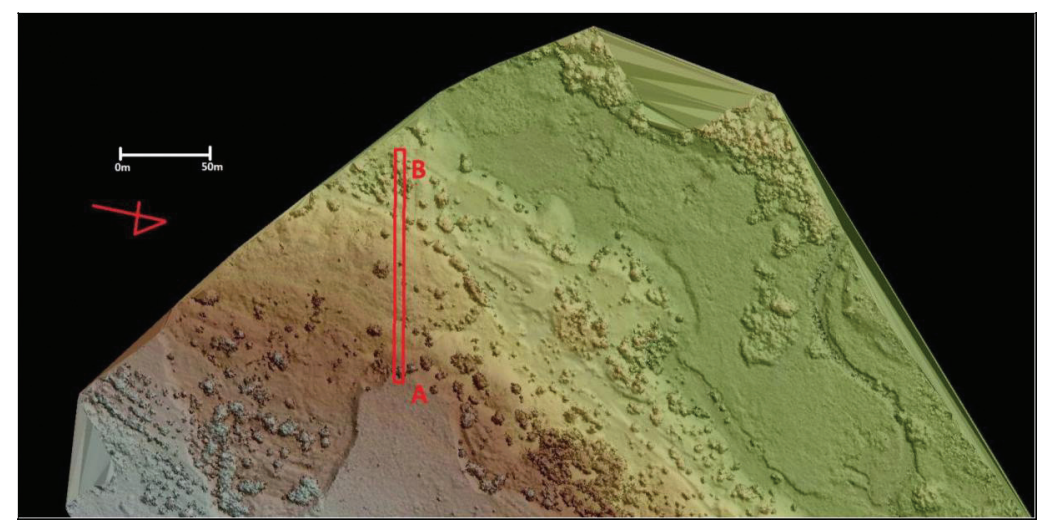

Fig. 13. Severynivka, Vinnytsia Oblast. Location of cross-section in the western escarp

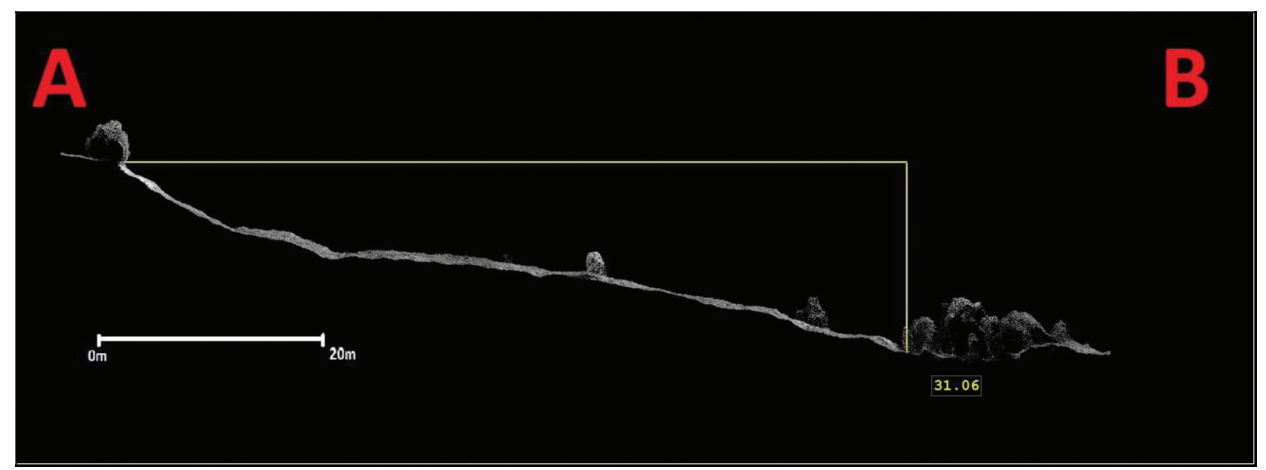

Fig. 14. Severynivka, Vinnytsia Oblast. Cross-section of the western escarp. Dimensions given in metres

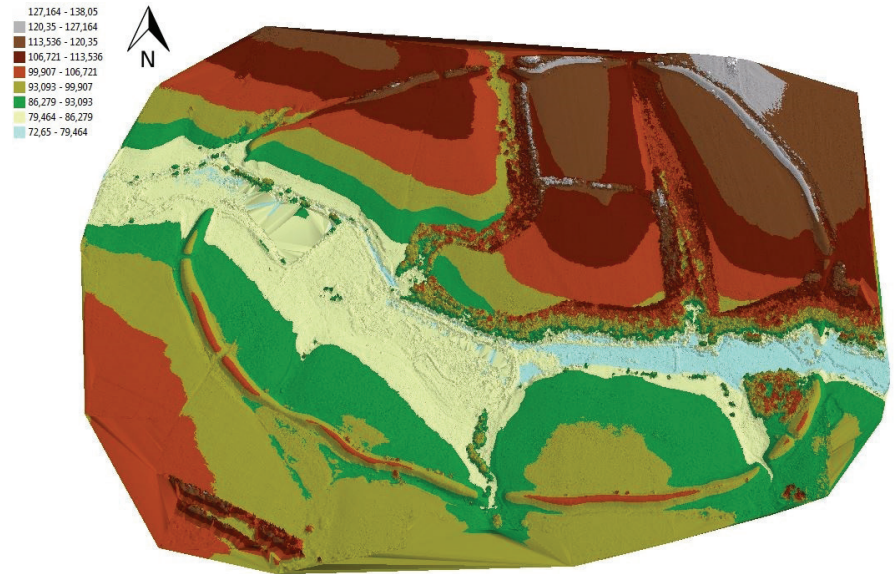

Fig. 15. Nemyriv, Vinnytsia Oblast - hypsometry 


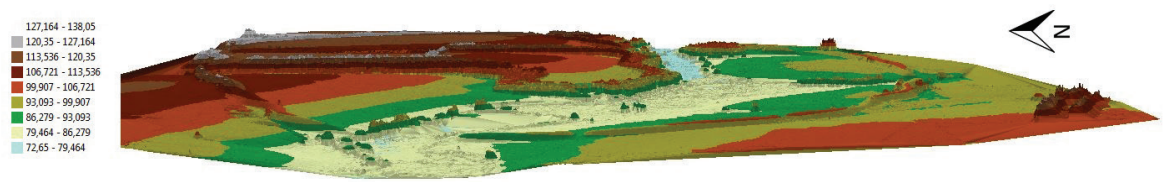

Fig 16 . Nemyriv, Vinnytsia Oblast. West view of the site - hypsometry

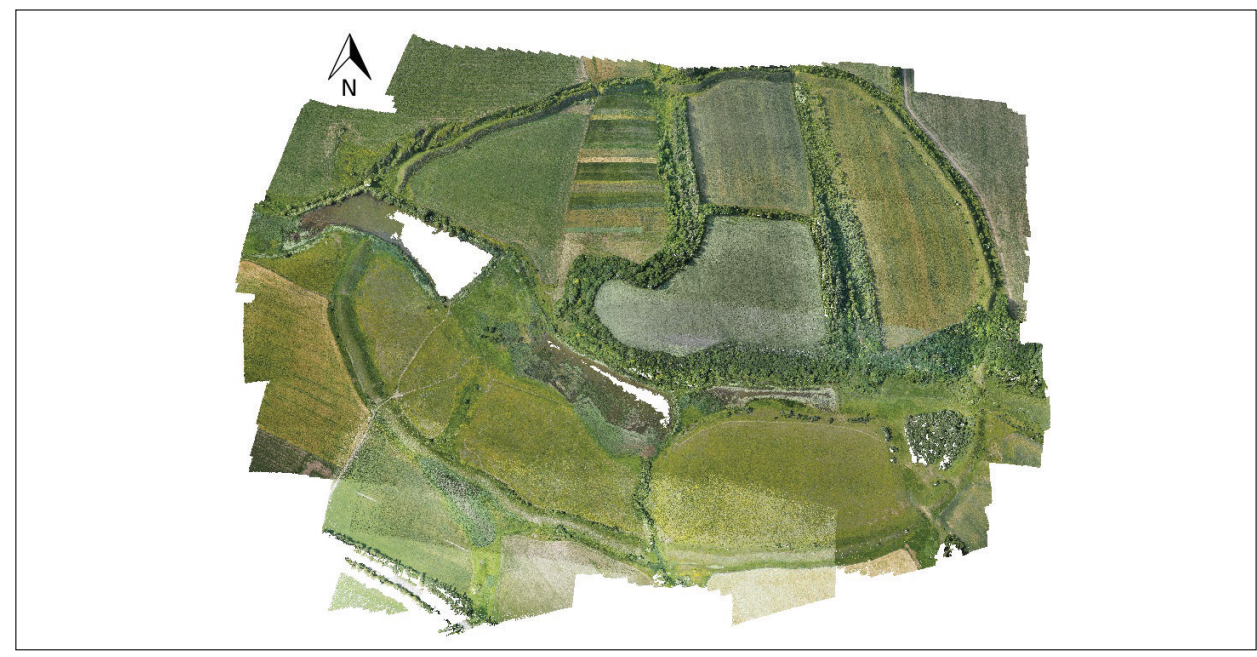

Fig. 17. Nemyriv, Vinnytsia Oblast - a point cloud

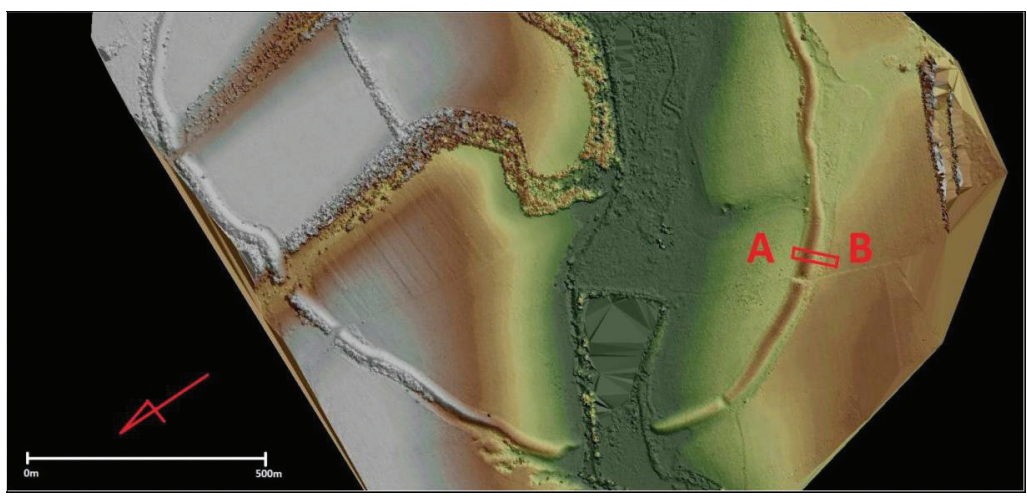

Fig. 18 . Nemyriv, Vinnytsia Oblast. Location of cross-section in the south-eastern part of hillfort fortifications 


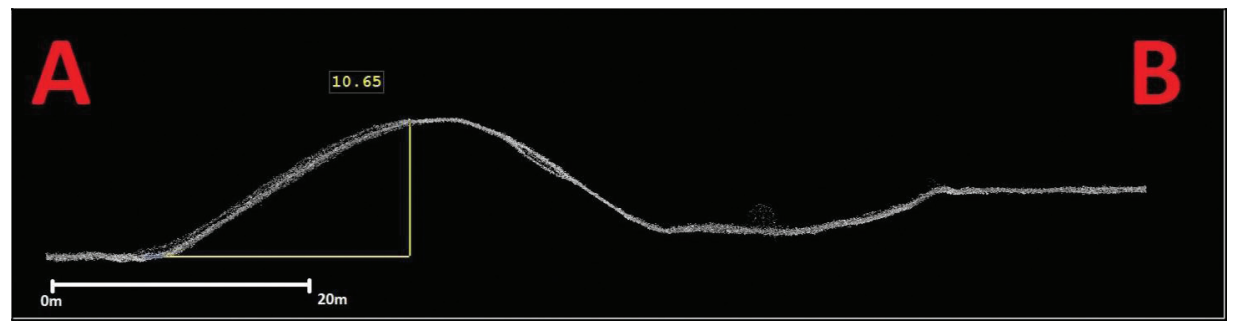

Fig. 19. Nemyriv, Vinnytsia Oblast. Cross-section of the rampart in the south-eastern part of hillfort fortifications. Dimensions given in metres

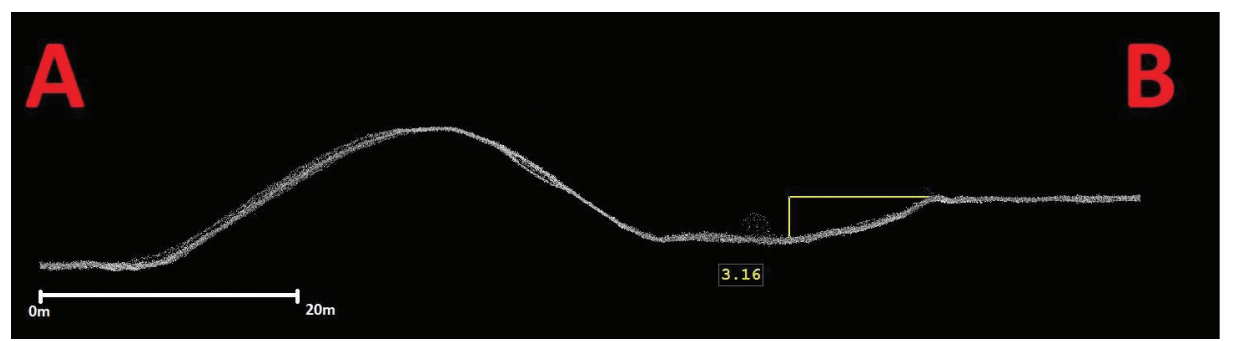

Fig. 20 . Nemyriv, Vinnytsia Oblast. Cross-section of the moat in the south-eastern part of hillfort fortifications. Dimensions given in metres

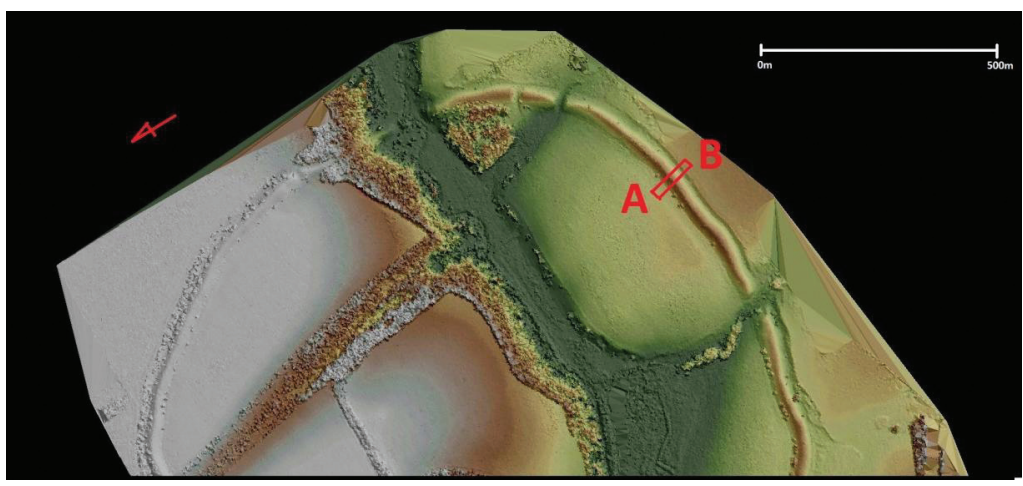

Fig. 21. Nemyriv, Vinnytsia Oblast. Location of cross-section in the southern part of hillfort fortifications 


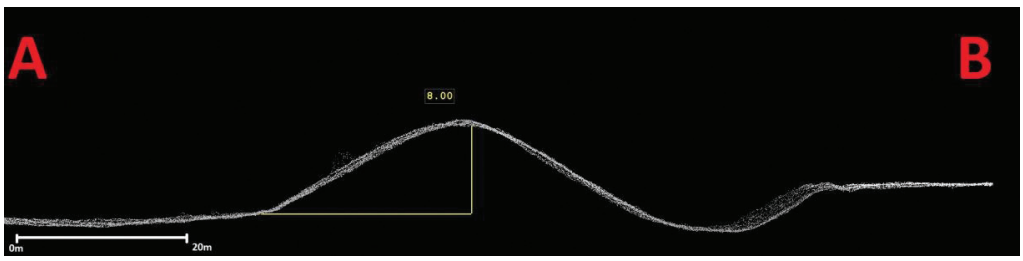

Fig. 22. Nemyriv, Vinnytsia Oblast. Cross-section of the rampart in the southern part of hillfort fortifications. Dimensions given in metres

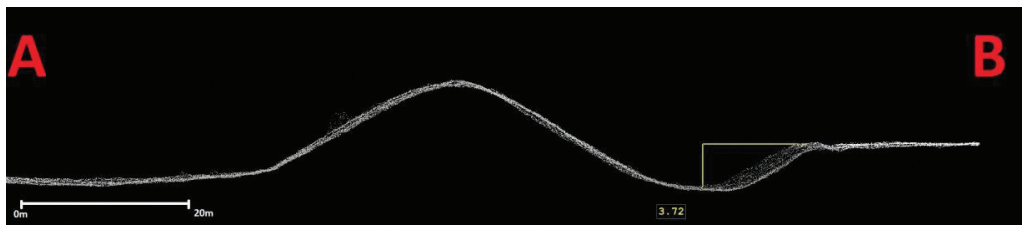

Fig. 23. Nemyriv, Vinnytsia Oblast. Cross-section of the moat in the southern part of hillfort fortifications. Dimensions given in metres

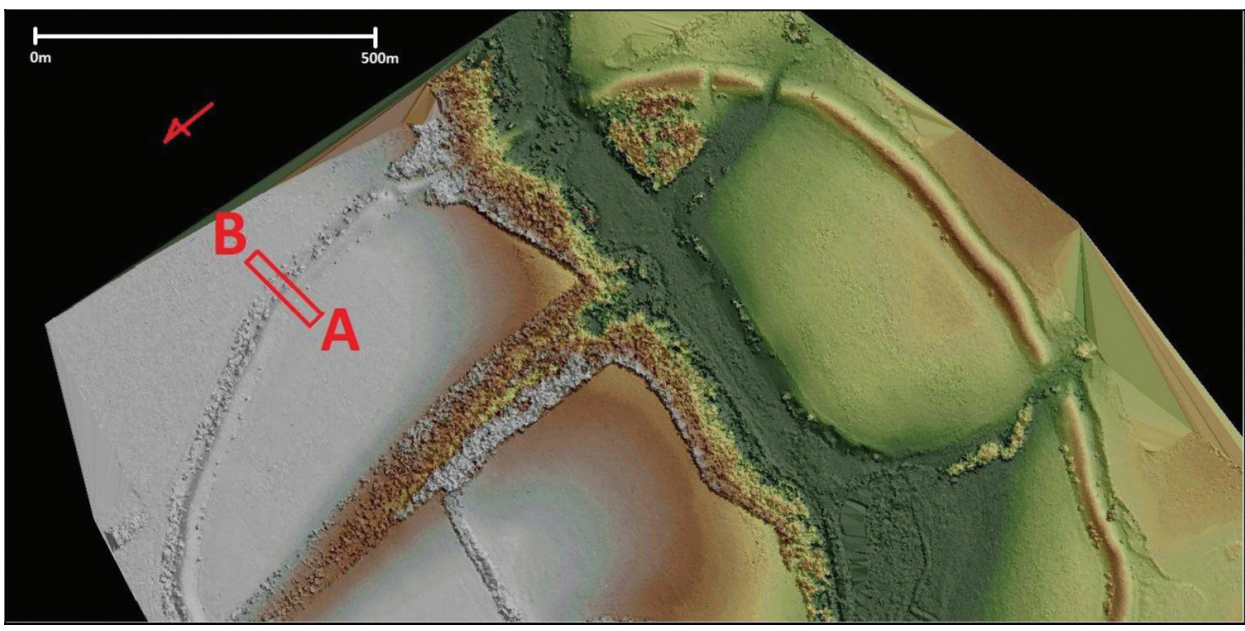

Fig. 24. Nemyriv, Vinnytsia Oblast. Location of cross-section in the eastern part of hillfort fortifications 


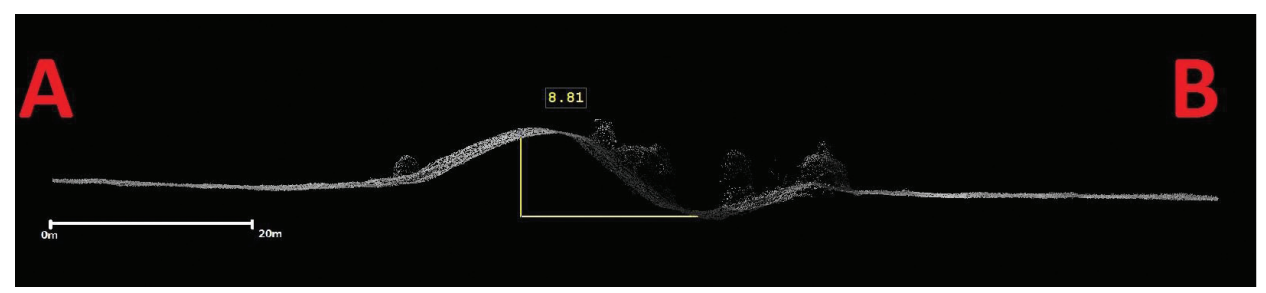

Fig. 25. Nemyriv, Vinnytsia Oblast. Cross-section of the rampart in the eastern part of hillfort fortifications. Dimensions given in metres

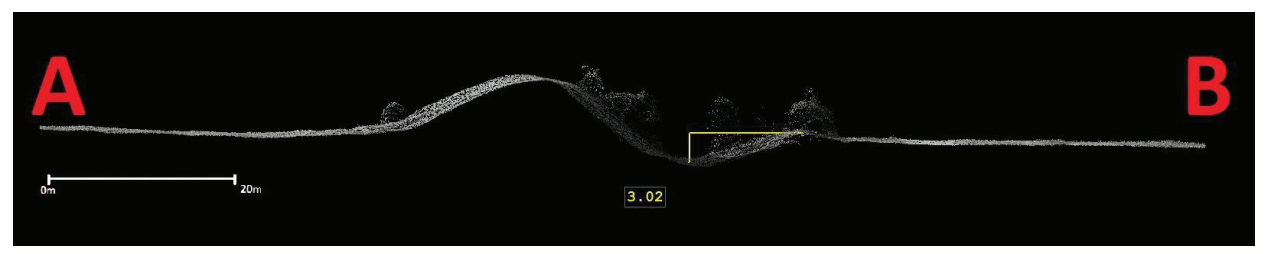

Fig . 26 . Nemyriv, Vinnytsia Oblast. Cross-section of the moat in the eastern part of hillfort fortifications. Dimensions given in metres

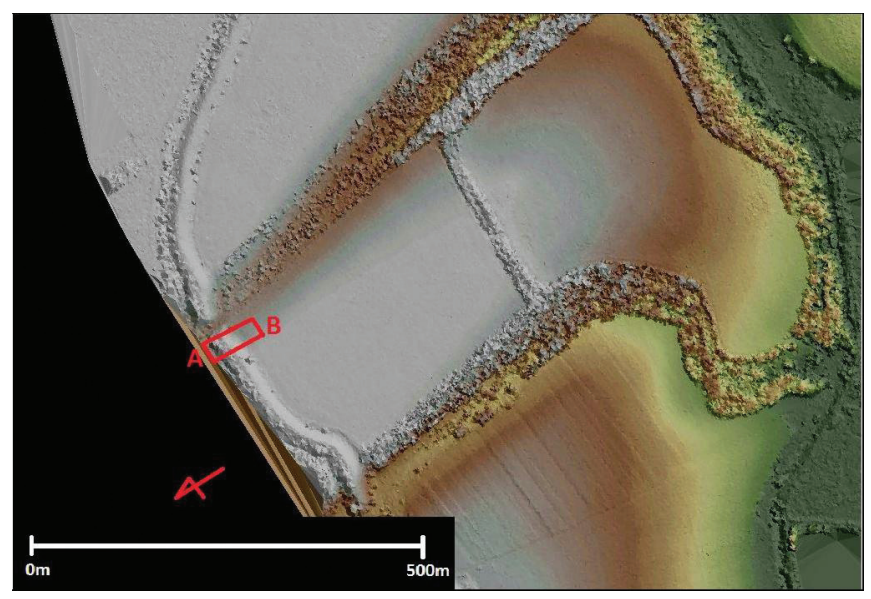

Fig. 27. Nemyriv, Vinnytsia Oblast. Location of cross-section in the northern part of hillfort fortifications 


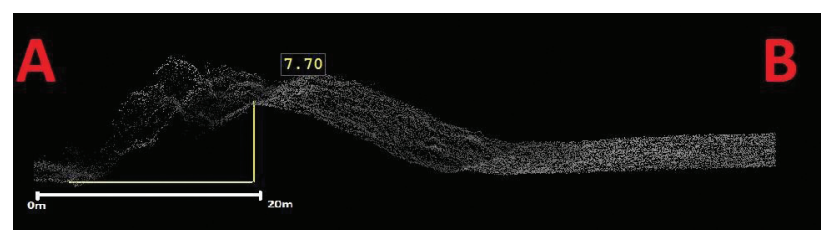

Fig. 28 Nemyriv, Vinnytsia Oblast. Cross-section of the rampart in the northern part of hillfort fortifications. Dimensions given in metres

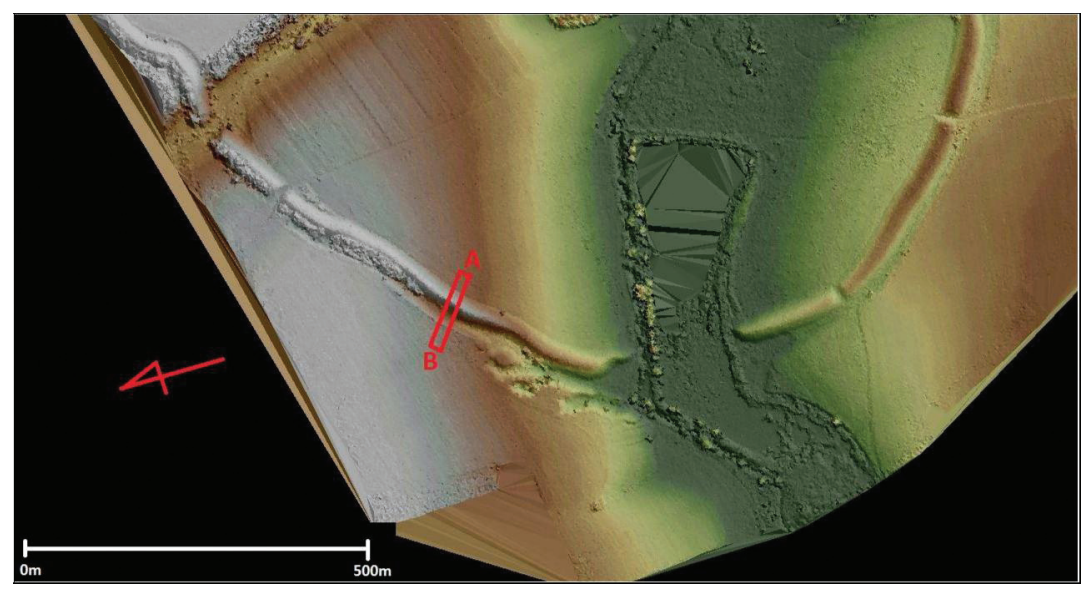

Fig. 29 Nemyriv, Vinnytsia Oblast. Location of cross-section in the north-western part of hillfort fortifications

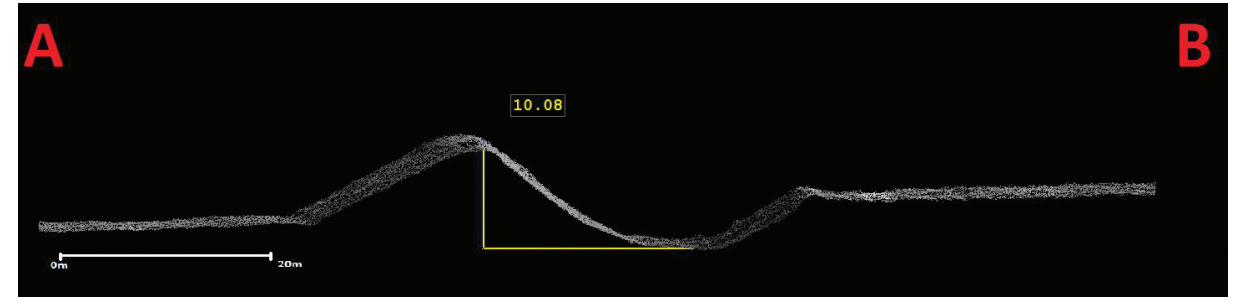

Fig. 30 Nemyriv, Vinnytsia Oblast. Cross-section of the rampart in the north-western part of hillfort fortifications. Dimensions given in metres 


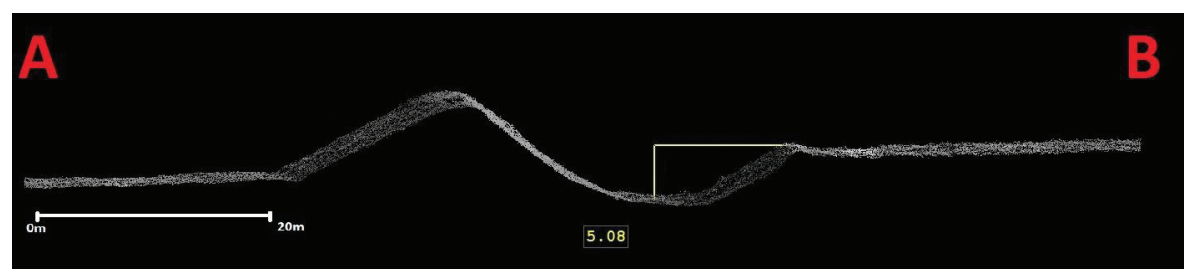

Fig. 31 Nemyriv, Vinnytsia Oblast. Cross-section of the moat in the north-western part of hillfort fortifications. Dimensions given in metres

2. NEMYRIV

The settlement in Nemyriv covers an area of 125 ha with its fortifications measuring $4100 \mathrm{~m}$ in length on the top of the ramparts (Figs. 15, 16, 17). The rampart in the south-western part (Fig. 18) measures $10.65 \mathrm{~m}$ in height, while being $42 \mathrm{~m}$ wide (Fig. 19). The ditch is $3.15 \mathrm{~m}$ deep and $21 \mathrm{~m}$ wide (Fig. 20). In the southern part (Fig. 21) the height of the ramparts is $8 \mathrm{~m}$, and their width $31 \mathrm{~m}$ (Fig. 22), the ditch is $3.70 \mathrm{~m}$ deep and $17 \mathrm{~m}$ wide (Fig. 23). The eastern rampart (Fig. 24) is $8.80 \mathrm{~m}$ high and $22 \mathrm{~m}$ wide (Fig. 25), with a $3 \mathrm{~m}$ deep and $20 \mathrm{~m}$ wide ditch (Fig. 26). The northern part of the fortifications (Fig. 27) is $7.70 \mathrm{~m}$ high, $34 \mathrm{~m}$ wide (Fig. 28), while the north-western part is $10 \mathrm{~m}$ high and $21 \mathrm{~m}$ wide (Fig. 30). In both cases the ditch is $5 \mathrm{~m}$ deep and $20 \mathrm{~m}$ wide (Fig. 31).

To sum up, this case study shows the usefulness of digital photogrammetry measurements for the identifying the size of the fortifications. They allow for measuring entire sites and specific fragments of each of the settlements. In addition, they provide indispensable heritage value, since the fortified settlement in Severynivka will be subject to further destruction due to the erosion of the escarpment. 


\section{REFERENCES:}

\section{Bernasik J.}

2008 Wyktady z fotogrametrii $i$ teledetekcji. Kraków, http://home.agh.edu. pl/ zfiit/mat_dydaktyczne_pliki/JB_wyklady.pdf, 18.03.2017.

\section{Daragan M.N.}

2010 Geoinformatsionnyi analiz transformatsii poselencheskikh struktur w nachale rannego zheleznogo veka $v$ Srednem Podneprove: sostoyanie problem $i$ perspektivy issledovaniya (held in archives of IA NANU).

Lobay B.M.

1986 Zhytlovi kompleksy horodyshcha bilia sela Mezhyrova na Vinnychyni. In: Tezy dopovidey IV Vinnytskoyi oblasnoyi istoryko-kraeznavchoyi konferentsiyi, 44-45. Vinnytsia.

\section{Smirnova G.I.}

1961 Severinovskoe gorodishche. Arkheologicheskiy sbornik Gosudarstvennogo Ermitazha 2: 88-103.

1996 Nemirovskoe gorodishche - obshchaya kharakteristika pamiatnika VII-VI vv. do n.e. Arkheolohiya 4: 67-84.

\section{Wężyk P.}

2015 Podręcznik dla użytkowników szkoleń z wykorzystania produktów LiDAR. Warszawa. 